Majalah Biomorfologi

Volume 30 Number 1, January 2020

pISSN:0215-8833, e.ISSN: 2716-0920, DOI: 10.20473/mbiom.v30i1.2020.7-13

\title{
Effects of low dose exposure of borax for 8 weeks on gastric ulcer formation
}

\author{
Audi Salman Faza ${ }^{1^{*}}$, Linda Dewanti ${ }^{* *} \mathbb{D}$, Ema Qurnianingsih $^{3} \mathbb{C}$ \\ ${ }^{1}$ Medical Program, Faculty of Medicine, Universitas Airlangga, Surabaya, Indonesia \\ ${ }^{2}$ Department of Public Health and Preventive Medicine, Faculty of Medicine, Universitas Airlangga, \\ Surabaya, Indonesia, ${ }^{3}$ Department of Physiology and Biochemistry, Faculty of Medicine, \\ Universitas Airlangga, Surabaya, Indonesia
}

\begin{tabular}{l}
\hline Article Info \\
\hline Article history: \\
Received Oct, 152019 \\
Revised Dec 1, 2019 \\
Accepted Dec 9, 2019 \\
Published Jan 1, 2020 \\
\hline
\end{tabular}

Keywords:

Low and high dose of

borax

Body weight

Gastric ulcer

Microscopic

Disease

Healthy lifestyle

Cancer

\begin{abstract}
Background: Borax, a carcinogenic toxicant, is illegally used as food additives frequently. Previous researches shown that high dose of borax exposure ( $300 \mathrm{mg} / \mathrm{kg}$ of BW) caused gastric ulcer, but low dose of borax, as found as usual dose in food, has not been frequently researched. Objective: The aim of this study was to analyze the effects of low dose of borax for 8 weeks on the formation of gastric ulcer. Materials and Methods: Twenty four young adult rats (Rattus norvegicus) were divided into 4 groups (Control, Group 1, 2 , and 3). Borax doses of $50 \mathrm{mg} / \mathrm{kg}, 150 \mathrm{mg} / \mathrm{kg}$, and $300 \mathrm{mg} / \mathrm{kg}$ were administered on groups 1,2 , and 3 respectively through sonde for 8 weeks; Control group was not exposed with borax. Body weight was monitored every 2 weeks. On the last day of the experiment, rats were euthanized and gastric ulcers were histopathologically analyzed using a microscope. The data were analyzed by the comparative test of Mann-Whitney and the significancy was set on $\mathrm{p}<0.050$. Results: The results showed that body weight was significantly different on the 6th week between Control vs Group 1 $(\mathrm{p}=0.010)$ and Control vs Group $3(\mathrm{p}=0.043)$. The grade of gastric ulcer was found higher in Group 2 and Group 3 compared to Control ( $p=0.019$ and 0.011 respectively). Conclusion: Both of low dose $(150 \mathrm{mg} / \mathrm{kg} \mathrm{BW})$ and high dose $(300 \mathrm{mg} / \mathrm{kg} \mathrm{BW})$ of borax exposure for 8 weeks cause microscopic gastric ulcer on rats.
\end{abstract}

\author{
\begin{tabular}{lll} 
(c) $(i)$ \\
\hline
\end{tabular} \\ Corresponding Author: \\ Audi Salman Faza \\ Faculty of Medicine, Universitas Airlangga \\ Jl. Mayjen. Prof. Moestopo no. 47, Surabaya 60131, East Java, Indonesia \\ audi.salman.faza-2016@fk.unair.ac.id \\ Linda Dewanti \\ Department of Public Health and Preventive Medicine, Faculty of Medicine, Universitas Airlangga \\ Jl. Mayjen. Prof. Moestopo no. 47, Surabaya 60131, East Java, Indonesia \\ linda-d@fk.unair.ac.id
}

\section{BACKGROUND}

Borax is a dangerous chemical that circulates freely in the community. Borax is basically used as an antiseptic and cleaning agent. In addition, borax is also used as a raw material for making detergents, wood preservatives, wood antiseptics, and cockroach control (Junianto, 2013). However, borax is also misused by fast food vendors as food preservatives. Foods that are mixed and preserved by borax will be dangerous to the body (Yulianto, 2013). Borax consumption can cause symptoms of illness such as 
nausea, abdominal pain, and diarrhea. It has also been discussed by Indonesian Minister of Health Regulation in 2012 that borax and similar compounds are chemicals that are prohibited from being used as preservatives in food products (Indonesian Minister of Health Regulation No.33 of 2012).

According to Junianto (2013), borax is still widely used as a preservative in traditional food/snacks. Borax is used by food vendors to maintain the texture and appearance of the food so that it can last a long time. Borax is often found in meatballs, dumplings, and soggy noodles (Junianto, 2013). Based on Pane et al research (2012), meatball sellers in Medan are still positively proven to use borax as a preservative in processed meatballs. This shows that there are still food sellers in Surabaya who do not know the dangers that can be caused by the use of borax as a food preservative. They choose borax as a food preservative because the price is relatively cheap compared to other food preservatives (Pane et al., 2012).

The effect of borax on the human body is so complex that it can cause damage to many internal organs, such as the liver, stomach, small intestine, large intestine, reproductive organs, spleen, senses, and even the central nervous system. In large quantities, borax can cause fever, anuria, hypotension, kidney damage, depression, cyanosis, and coma. More severe cases include coma, convulsions, anemia, failed circulation, and even death. (Pane et al., 2012).

Borax contains dangerous compounds-namely boric acid-as it can damage body cells. Boric acid that enters the body can damage cells by inhibiting the formation of ATP in these cells. Cell that cannot produce ATP optimally will degenerate due to the inability of the cell to pump sodium ions out of the cell. The accumulated sodium ions cause water retention in the cytoplasm of cells and cause cloudy swelling. Cell can still recover if the degeneration is sub-lethal. If degeneration lasts a long time, the cell cannot metabolize optimally and will experience cell death, or necrosis (Eren et al., 2012).

Symptoms that often occur as a result of borax consumption are nausea, abdominal pain, and vomiting (Pane et al., 2012). This shows the existence of abnormalities or damage from the digestive organs, especially the stomach. In theory, borax can damage cells in the stomach wall, especially surface mucous cell. Surface mucous cell secretes alkaline liquid containing mucin to protect the stomach wall from stomach acid. If this cell is damaged, the ability to produce mucin is disrupted. The stomach wall cannot hold stomach acid and will erode so that ulcers can occur (Zatorski, 2017).

In existing research, exposure to borax at a dose of $300 \mathrm{mg} / \mathrm{kg} \mathrm{BW}$ for 28 days in wistar strain rats caused cell erosion and desquamation (Aryyagunawan \& Rohmah, 2013). Microscopically, damage to the stomach wall that can occur due to borax exposure is cell desquamation, cell erosion, to cell ulceration. Exposure to borax for the stomach in a longer period of time is not known with certainty because not much research has been done. In a minimal effect, damage to the stomach wall due to borax exposure is inflammatory process (gastritis) which will cause symptoms such as nausea, vomiting, and loss of appetite. These symptoms can cause weight loss (Aryyagunawan \& Rohmah, 2013).

The effect of borax exposure in daily food doses on the stomach has not been researched much either. The dose of borax in foods that can be tolerated by humans is $4,000 \mathrm{mg} / \mathrm{kg}$ of food (European Food Safety Authority, 2013). However, several studies show that the borax content found in 9 types of snacks in South Tangerang exceeded the tolerable limit, that are $6,609 \mathrm{mg} / \mathrm{kg}$ and $17,640 \mathrm{mg} / \mathrm{kg}$ of food (Rumanta et al., 2016). It needs further investigation as it can cause disaster for consumers.

\section{OBJECTIVE}

The researchers want to analyze the effect of multilevel dose (dose and reference dose in previous studies) of borax exposure over a longer time period, that are 8 weeks ( 2 months), on macroscopic and microscopic formation of ulcers on the stomach, along with changes in rat body weight. The gastric was chosen as the organ under study because it is an organ that is first exposed to boric acid chemicals before it is absorbed into the circulatory system.

\section{MATERIALS AND METHODS}

This research was conducted at the Rat Cage, Department of Anatomy, Histology and Pharmacology, Faculty of Medicine, Universitas Airlangga, Surabaya, Indonesia. This research has been declared ethical with an ethics-worthy certificate number 265/EC/KEPK/FKUA/2019 and the experiment began in November - December 2018. 
The sample used was taken from a population of wistar rats (Rattus norvegicus) as many as 24 rats, which are determined using the federer formula. Twenty-four rats were randomly selected by using the inclusion criteria, namely male, 1.5 months old, 100 grams, and not sick (actively moving), while exclusion criteria included rats that did not meet the inclusion criteria. The 24 rats were then divided into 4 groups based on their treatment, namely 1 control group and 3 treatment groups. The control group did not receive any treatment, while the other three treatment groups were given borax consumption at different doses.

The first reference dose used is based on the content of borax contained in ready-to- consume soggy noodles, which is $6.609 \mathrm{mg} / \mathrm{kg}$ and $17.640 \mathrm{mg} / \mathrm{kg}$ of food (Rumanta et al., 2016). Borax dose in foods that can be tolerated by humans is $4.000 \mathrm{mg} / \mathrm{kg}$ of food (European Food Safety Authority, 2013). The dose was then converted to rat doses using a dose conversion table, which is $50 \mathrm{mg} / \mathrm{kg} \mathrm{BW}$ and 150 $\mathrm{mg} / \mathrm{kg} \mathrm{BW}$ (Nair \& Jacob, 2016). The third reference dose is $300 \mathrm{mg} / \mathrm{kg} \mathrm{BW}$ taken from the reference dose in the study of Aryyagunawan \& Rohmah (2013), in which at that concentration, microscopic ulcers was found in rat gastric. Therefore, the determined doses are 50,150 , and $300 \mathrm{mg} / \mathrm{kg} \mathrm{BW}$ of rats. Because the body weight of rats is 100 grams, the dose of borax given for each rat is 5,15 , and 30 $\mathrm{mg} / \mathrm{rat}$.

Consumption method is by dissolving borax with each dose in distilled aqua as much as $1 \mathrm{ml}$. Borax liquid was then given intragastric using sonde in rats. The sonde is done once a day for 8 weeks, and each treatment was repeated six times according to the number of rats per group. The details of the treatment are as follows: 1) C: White rats are not given any treatment, 2) T1: White rats are given a 5 $\mathrm{mg} / \mathrm{ml} / \mathrm{rat} /$ day borax liquid, 3) $\mathrm{T} 2$ : White rats are given a $15 \mathrm{mg} / \mathrm{ml} / \mathrm{rat} /$ day borax liquid, and 4) $\mathrm{T} 3$ : White rats are given $30 \mathrm{mg} / \mathrm{ml} / \mathrm{rat} /$ day borax liquid

White rats during 2 months of borax exposure were weighed every 2 weeks to measure their weight. The last body weight of rats was weighed after exposure to borax on the last day and before euthanasia. After 8 weeks, all the rats were euthanized by being exposed with Diethyl Ether through inhalation. Euthanized rats would be dissected and their stomach would be taken. The stomach was then cut and fixated with formaldehyde solution in order to make specimens. Specimens were analyzed by adjusting several aspects, such as temperature, size, volume ratio, time, $\mathrm{pH}$, and osmolality. Specimens were then observed under a microscope with 400x magnification in order to observe the formation of microscopic ulcers, namely in the form of epithelial desquamation, epithelial erosion, or epithelial ulceration. Microscopic assessment was carried out using the Barthel Manja scoring (Adinugroho et al., 2013), contained in the operational definition of the variable above. Observations were done on rat body weight in every 2 week. Rats' body weight on the last day was averaged by each group and presented in the form of data.

Data of rat body weight and the scoring of gastric ulcer above were then tested for normality by using Shapiro-Wilk test (sample size <50) to determine whether the data distribution is normal or not. If the distribution of data proves to be abnormal, a non- parametric comparison test is performed. The nonparametric comparison test chosen is Kruskal-Wallis test. If Kruskal-Wallis test on a variable proves to be significant, a more specific comparative test between groups is conducted, namely Mann-Whitney to determine the significant difference between one group and another group in one variable.

\section{RESULTS}

\section{Rat weight}

Data were obtained as a whole after weighing the last rat weight, namely at week 8 . A special table can also be found written in "Raise of BW in total" that is, the difference in body weight of rats that were weighed between week 0 and week 8 . The weight of each group at every week is presented by the mean (average) and standard deviation as above.

Normality test Shapiro Wilk showed that the rats' weight from week 0 to week 8 had normal data distribution, so it was necessary to do a comparison test between non-parametric groups (KruskalWallis and Mann-Whitney). From the test results Kruskal-Wallis, it was found that there was a significant difference in the distribution of rat body weight data in week $6(\mathrm{p}=0.031)$. With MannWhitney test, a significant difference in body weight of rats was obtained in the week 6 , namely between the control group vs the $5 \mathrm{mg} / \mathrm{ml}$ borax dose group ( $\mathrm{p}=0.010$ ), and between the control group and the $30 \mathrm{mg} / \mathrm{ml}$ borax dose group $(\mathrm{p}=0.043)$. 
Table 1. Data distribution of rats' body weight

\begin{tabular}{ccccccc}
\hline Borax Dose & \multicolumn{5}{c}{ Weight in Mean (SD) gram } \\
\cline { 2 - 6 } Group (mg/ml) & Week 0 $^{\S}$ & Week 2 & Week 4 & Week 6 & Week 8 & $\begin{array}{c}\text { Raise of BWin } \\
\text { total }\end{array}$ \\
\hline Control & $130.83^{\mathrm{a}}$ & 173.66 & 206.83 & $247,16^{\mathrm{a}}$ & 264.83 & $(134$ \\
& $(8.06)$ & $(18.44)$ & $(19.27)$ & $14: 6$. & $(15.44)$ & $(15.89)$ \\
\hline 5 & $122.33^{\mathrm{a}}$ & 161.66 & 189.83 & $220.33^{\mathrm{b}}$ & 237 & 114.66 \\
& $(10,25)$ & $(6.34)$ & $(8.35)$ & $9(45)$ & $(8.83)$ & $(13.57)$ \\
\hline 15 & $125.33^{\mathrm{a}}$ & 176 & 209,16 & $245.66^{\mathrm{a}}$ & 264.66 & 139.33 \\
& $(9.62)$ & $(15.07)$ & $(21.8)$ & $(28.98)$ & $(32.19)$ & $(29.77)$ \\
\hline 30 & $120.83^{\mathrm{a}}$ & 157.83 & 186.66 & $215.33^{\mathrm{b}}$ & 234.66 & 116,16 \\
& $(6.73)$ & $(14.44)$ & $(22.46)$ & $(25.45)$ & $(31.48)$ & $(25.19)$ \\
\hline
\end{tabular}

$\S$ : Week 0: There was no significant difference in weight between groups ( $\mathrm{p}$ value $=0.205$ with

Kruskal-Wallis test)

T: Week 6: There was a significant difference in weight between groups ( $\mathrm{p}=0.031$ with Kruskal- Wallis test) i.e. in the Control Group vs Borax Dose Group 5mg/ml (Mann-Whitney test $\mathrm{p}=0.010$ ) and Control Group vs Borax Dose Group 30mg/ml (Mann-Whitney test $\mathrm{p}=0.043$ ). Different alphabets show significant differences

\section{Gastric ulcer}

Data distribution of rats' gastric microscopic images obtained from this research experiment is as follows:

Table 2. Data distribution of the microscopic rat ulcer score

\begin{tabular}{cllll}
\hline \multirow{2}{*}{$\begin{array}{c}\text { Borax Dose Group } \\
(\mathrm{mg} / \mathrm{ml})\end{array}$} & 0 & 1 & 2 & 3 \\
\cline { 2 - 5 } & 3 & 3 & 0 & 0 \\
\hline Control $^{\mathrm{a}}$ & 1 & 4 & 1 & 0 \\
$5^{\mathrm{a}}$ & 0 & 3 & 3 & 0 \\
$15^{\mathrm{b}}$ & 0 & 2 & 4 & 0 \\
$30^{\mathrm{b}}$ & & &
\end{tabular}

0: no pathological changes
1: epithelial desquamation
2: epithelial erosion
3: epithelial ulceration

Different alphabets show significant differences, i.e. Control vs Group 2 and Control vs Group 3 (p values $=0.019$ and 0.011 respectively with Mann-Whitney test).

In the data distribution, it was obtained that the most pathological changes found were cell desquamation (value $=1$ ), then followed by epithelial erosion (value $=2$ ). Some data were found to have no pathological changes at all (value $=0$ ) and totaled 4 . No data were found to have epithelial ulceration (value $=3$ ). No data are lost or damaged and all data have been successfully observed.

With Shapiro-Wilk normality test, it was found that the distribution of data was not normal in all dose groups, so a non-parametric comparative test was needed (Kruskal-Wallis and Mann-Whitney). With Kruskal-Wallis test, it was found a significant difference of 2 degrees of gastric rat ulcer values in 2 or more groups with $\mathrm{p}$ value $=0.019$; and with Mann- Whitney test, there was a significant difference between the control group and the $15 \mathrm{mg} / \mathrm{ml}$ borax dose group $(\mathrm{p}=0.019)$ and the control group vs the $30 \mathrm{mg} / \mathrm{ml}$ borax dose group $(\mathrm{p}=0.011)$.

By microscopic observation, the control group showed a normal picture of the gastric mucosa (all layers are still intact). The $5 \mathrm{mg} / \mathrm{ml}$ and $15 \mathrm{mg} / \mathrm{ml}$ borax dose groups showed a picture of desquamated gastric mucosa (erosion of the outer layer of gastric mucosa). The $30 \mathrm{mg} / \mathrm{ml}$ borax dose group showed a picture of a gastric mucosa having erosion or erosion of the stomach mucosa that is deep enough, but does not penetrate the mucosal muscular layer, and is accompanied by signs of inflammation. The microscopic pictures of the gastric mucosa are as follows: 


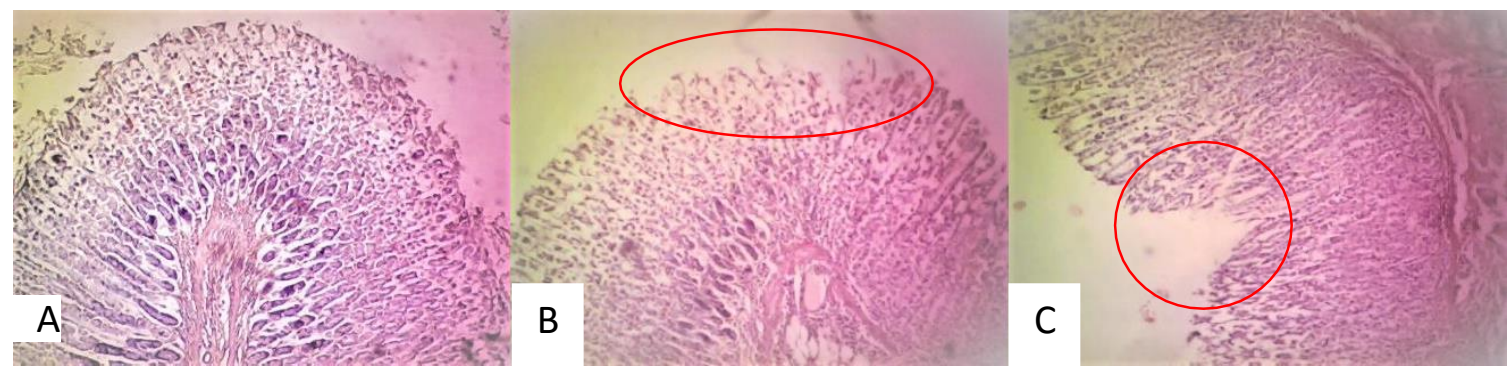

Figure 1. Histological features of 400x enlarged rat mucosa: A. Normal gastric mucosa, taken from the control group data; B. Desquamation of gastric mucosa (red circle), taken from the group dose of borax $15 \mathrm{mg} / \mathrm{ml}$; C. Gastric mucosal erosion (red circle), taken from the group dose of $30 \mathrm{mg} / \mathrm{ml}$ borax.

\section{DISCUSSION}

\section{Effect of borax on the body}

Borax (Na2B4O7.10H2O) consumed by the body will initially enter the upper digestive system (stomach), and then it will react with hydrochloric acid $(\mathrm{HCl})$ which is synthesized by the parietal gland cells of the stomach so that it is quickly synthesized by chemical reactions between borax and stomach acid $(\mathrm{HCl})$ as follows: $\mathrm{Na} 2 \mathrm{~B} 4 \mathrm{O} 7.10 \mathrm{H} 2 \mathrm{O}+2 \mathrm{HCl} \rightarrow 4 \mathrm{H} 3 \mathrm{BO} 3+2 \mathrm{NaCl}+\mathrm{H} 2 \mathrm{O}$. These results in the formation of boric acid compounds (H3BO3) (Juhana et al., 2016).

Boric acid which is spread throughout the body through the circulatory system will damage cells by reducing the formation of ATP in these cells (Eren et al., 2012). The part of the cell that is attacked by boric acid is primarily the mitochondria (See et al., 2010). Mitochondria are organelles in cells that function to produce energy for cell survival through cell respiration in eukaryotic organisms. The respiration of our body cells involves the process of oxidative phosphorylation. In oxidative phosphorylation, NAD + binds to the $\mathrm{H}+$ and form NADH. NADH by the electron transport process will form 2 ATP per molecule Boric acid is able to binds strongly to $\mathrm{H}+\mathrm{H}+$ is necessary for cell metabolism by binding to NA+. The lack of NADH bonds will disrupt the metabolic processes in cells. This results in the failure of the oxidation-reduction reaction in the mitochondria (See et al., 2010)

Cells that cannot produce ATP optimally can degenerate until they become necrosis. Cells need ATP to activate the sodium ion pump $(\mathrm{Na}+)$ and potassium ion $(\mathrm{K}+)$ among cell membranes. If the pump process is inhibited, $\mathrm{Na}+$ will accumulate in cells, and the ability of $\mathrm{Na}+$ to retains water causes accumulation of water in the cytoplasm so that the cells become swollen (cloudy swelling). If the accumulation of water happens for a long time, metabolism in cells can be disrupted and ultimately cause cells to experience necrosis (Eren et al., 2012).

In the stomach, boric acid can damage cells in the stomach wall, especially surface mucous cell. Surface mucous cell functions to secrete alkaline liquid containing mucin to protect the stomach wall from stomach acid. If this cell is damaged, the ability to produce mucin is disrupted. The stomach wall cannot hold stomach acid and will erode so that ulcers can occur (Zatorski, 2017).

In a minimal effect, damage to the stomach wall that can occur is inflammation of the stomach cells that cause gastritis. Gastric cell inflammation (gastritis) can cause symptoms such as nausea, vomiting, diarrhea, and loss of appetite which can ultimately lead to weight loss. This shows that the degree of damage to the stomach wall caused by exposure to borax with minimal doses can be measured by considering the body weight of the borax consumer.

\section{Relationship between borax dose and rat weight}

Rats given borax can suffer from decreased appetite due to nausea and diarrhea, which in turn causes weight loss. Rats used as experimental objects in this study have certain inclusion criteria, which have a weight of 100-150 grams. This weight is generally found in young rats, and that is age of +1 month. As rats grow, they will gain weight until when they are adults, the body weight of rats will reach 300800 grams (Ades, 2018). This study uses ideal aged rats, namely young rats, aged +1 month, therefore, this study did not directly examine rat weight loss, but by observing the inhibition of weight gain in rats that were still in its infancy. 
In the rat body weight data distribution, a significant difference was found, namely in the week 6 of rat weight distribution. The weight of rat in the week 6 was the weight of the rat which had increased since week 0 (body weight of the rat before being given treatment), and in the distribution of body weight data of week 0 , there was no significant difference, because the body weight of the rat had been controlled using inclusion criteria. In the distribution of rat body weight data in the other week, it was found differences in body weight growth of rats among borax dose groups, but the difference was not significant. The body weight of rats in the treatment 2 group $(150 \mathrm{mg} / \mathrm{kg}$ body weight) was also lower than in the control group, but the difference was not significant. This can be caused by other factors that influence the body weight of rats, such as psychological stress factors (Patterson \& Abizaid, 2013). In that study, it was said that chronic stress can interfere with metabolic processes in the body, causing the risk of obesity, diabetes mellitus type 2, and cardiovascular disease. In the comparison among groups on the variable of raise body weight in total, also no significant difference was found.

The results of Mann-Whitney test stated that there was a significant difference between the distribution of control group data with the treatment dose group $1(50 \mathrm{mg} / \mathrm{kg}$ body weight), and between the control group data distribution with treatment dose group $3(300 \mathrm{mg} / \mathrm{kg}$ body weight). This difference was marked by the average body weight of rats in the treatment group 1 and 3 lower than in the control group. In general, borax has been shown to cause inhibition of weight gain in rats, and the results of this study are in line with the research of Aysan et al. (2011). According to Aysan et al. (2011), Boron compounds in borax can increase liver activity in catalyzing glycogen, and in his research, an increase in glucose, cholesterol, HDL, and triglyceride levels was found in rat urine of the treatment group exposed to boric acid at a dose of $0.2 \mathrm{mg} / \mathrm{kg}$ compared to the control group. In that study, the treatment group $(0.2 \mathrm{mg} / \mathrm{kg})$ experienced a significant weight loss compared to the control group (Aysan et al., 2011).

\section{Relationship between borax dose and gastric ulcer}

Kruskal-Wallis test stated that there was a significant difference in the value of the degree of microscopic gastric ulcer among groups $(\mathrm{p}=0.019)$. In the distribution of these data, no epithelial ulceration was found (value $=3$ ). These results are in line with the study of Aryyagunawan \& Rohmah (2013) where exposure to borax with a dose of $300 \mathrm{mg} / \mathrm{kg}$ in rats does not cause epithelial ulceration in the stomach of the rat, and only in the form of gastric epithelial erosion and desquamation. In the control group, epithelial desquamation was obtained, although the group was not given any treatment. This is normal, due to many factors that can influence ulcer formation in the stomach of rats, as the research of Deding et al., (2016) states that psychological stress increases the risk of gastric ulcer (Deding et al., 2016). However, the marked formation of gastric mucosal erosion (epithelial erosion) was only obtained in treatments 1,2 and 3, in different amount. Most epithelial erosion was distributed in treatment group $2(150 \mathrm{mg} / \mathrm{kg}$ borax BW) and $3(300 \mathrm{mg} / \mathrm{kg}$ borax BW) with the treatment group having slightly more epithelial erosion than treatment group 2 . In treatment group $1(50 \mathrm{mg} / \mathrm{kg}$ borax dose), only 1 data was found with epithelial erosion.

The results of Mann-Whitney test showed no significant difference between the distribution of control group data with treatment group $2(150 \mathrm{mg} / \mathrm{kg}$ borax BW) and between the control group with treatment $3(300 \mathrm{mg} / \mathrm{kg}$ borax BW). In the comparison between the control group and treatment group $1(50 \mathrm{mg} / \mathrm{kg} \mathrm{BW})$, no significant difference was found. The results of this test stated that the formation of microscopic ulcers in the stomach of rats was proven significantly in the treatment group with a dose of $150 \mathrm{mg} / \mathrm{kg}$ borax and $300 \mathrm{mg} / \mathrm{kg}$ borax as proven in research by Aryyagunawan \& Rohmah (2013) which used a dose of $300 \mathrm{mg} / \mathrm{kg} \mathrm{BW}$, and not proven at a dose of $50 \mathrm{mg} / \mathrm{kg} \mathrm{BW}$ borax.

\section{CONCLUSION}

There was an effect of multilevel doses (low and high) exposure of borax for 8 weeks on the formation of ulcers in gastric rat (Rattus norvegicus), i.e. at $150 \mathrm{mg} / \mathrm{kg} \mathrm{BW}$ borax dose and $300 \mathrm{mg} / \mathrm{kg}$ $\mathrm{BW}$ rat compared with controls.

\section{REFERENCES}

Ades, E., 2018. Species Specific Information: Rat. Downloaded 4 Juli 2018 from http://web.jhu. edu/animalcare/procedu res/rat.html. 
Adinugroho, N., Rohmah, I., Santoso, S. 2013. Pengaruh pemberian boraks dosis bertingkat terhadap perubahan gambaran makroskopis dan mikroskopis hepar selama 28 hari (Studi pada tikus Wistar) [Effect of incremental borax administration on the change of macro- and microscopic hepatic profile in 28 days. A study on Wistar rats]. Jurnal Kedokteran Diponegoro, 2(1)

Aryyagunawan,G., Rohmah, N., 2013. Pengaruh pemberian boraks dosis bertingkat terhadap perubahan makroskopis dan mikroskopis gaster tikus wistar selama 4 minggu [The effect of stratified borax doses on macroscopic and microscopic changes in the gastric of Wistar rats for 4 weeks]. Undergraduate Thesis. Semarang: Universitas Diponegoro.

Aysan, E., Sahin, F., Telci, D., Yalvac, M., Emre, S., Karaca, C., Muslumanoglu, M., 2011. Body weight reducing effect of oral boric acid intake. International Journal of Medical Sciences, 8(8): 6538.

Deding, U., Ejlskov, L., Grabas, M., Nielsen, B., Torp-Pedersen, C., Bøggild, H., 2016. Perceived stress as a risk factor for peptic ulcers: a register-based cohort study. BMC Gastroenterology, 16(1): 140.

Eren, M., Uyanik, F., Kocaoglu G,B., Atasever, A., 2012. The influence of dietary boron supplementation on performance, some biochemical parameters and organs in broilers. Asian Journal of Animal and Veterinary Advances, 7(11): 1079-89.

European Food Safety Authority, 2013. Scientific opinion on the re-evaluation of boric acid (E 284) and sodium tetraborate (borax) (E 285) as food additives. EFSA Journal 2013, 11(10): 3407.

Juhana, Hakim A., Rohmah, I.N., 2016. Pengaruh pemberian boraks dengan dosis bertingkat terhadap perubahan makroskopis dan mikrokskopis ginjal tikus Wistar selama 4 minggu dilanjutkan 2 minggu tanpa paparan boraks [Effect of 4-week incremental borax administration on Wistar rats renal macroand microscopic changes followed with 2-week without borax]. Jurnal Kedokteran Diponegoro, 5(1): $65-70$.

Junianto, C., 2013. Analisis boraks pada bakso daging sapi a dan b yang dijual di daerah Kenjeran Surabaya menggunakan spektrofotometri [Borax analysis on beef meatballs a and $b$ sold in the kenjeran area of Surabaya using spectrophotometry]. Calyptra, 2(1): 1-10.

Ministry of Health, Republic of Indonesia, 2012. Peraturan Menteri Kesehatan Republik Indonesia Nomor 33 Tahun 2012 tentang Bahan Tambahan Pangan [Regulation of the Minister of Health of the Republic of Indonesia Number 33 of 2012 on Food Additives]. Berita Negara Republik Indonesia Tahun 2012 No. 757. Jakarta: Sekretariat Negara.

Nair, A., Jacob, S., 2016. A simple practice guide for dose conversion between animals and human. Journal of Basic and Clinical Pharmacy, 7(2): 27.

Pane, Imee S. Nuraini, D., Chayaya, I., 2012. Analisis kandungan boraks (Na2b4o7 10 H2o) pada roti tawar yang bermerek dan tidak bermerek yang dijual di kelurahan padang bulan kota Medan tahun 2012 [Analysis of borax content in branded and unbranded bread sold in Padang Bulan Village, Medan, 2012]. Lingkungan dan Keselamatan Kerja, 2(3).

Patterson, Z. Abizaid, A., 2013. Stress induced obesity: lessons from rodent models of stress. Frontiers in Neuroscience, 7(7):130.

Rumanta, M. Iryani, K. Ratnaningsih, A., 2016. Analisis kandungan boraks pada makanan: studi kasus di wilayah Kecamatan Pamulang, Tangerang Selatan [Analysis of borax content in food: a case study in the Pamulang District, South Tangerang]. Jurnal Matematika, Sains, dan Teknologi 17(1): 40-9.

See, A. Salleh, A. Bakar, F. Yusof, N. Abdulamir, A. Lee, Y., 2010. Risk and health effect of boric acid. American Journal of Applied Sciences, 7(5): 620-7.

Yulianto, D., 2013. Analisis boraks dalam sampel bakso sapi I, II, III, IV, V, VI, VII, dan VIII yang beredar di Pasar Soponyono dan Pasar Jagir [Borax analysis in beef meatball samples I, II, III, IV, V, VI, VII, and VIII circulating in Soponyono Market and Jagir Market]. Undergraduate Thesis. Surabaya: Universitas Airlangga.

Zatorski, H., 2017. Pathophysiology and risk factors in peptic ulcer disease. Introduction to Gastrointestinal Diseases, 2: 7-2. 